\title{
РОЗВИТОК СОЦАЛЬНИХ КОМПЕТЕНТНОСТЕЙ СТУДЕНТІВ ВИЩОЇ ОСВІТИ У ВЕЛИКОБРИТАНІЇ
}

\author{
Зарудна I. А. \\ здобувач третього (освітньо-наукового) рівня вищої освіти кафедри \\ початкової і професійної освіти, Харківський національний педагогічний \\ університет імені Г. С. Сковороди, м. Харків, Україна
}

Стаття присвячена аналізу інструментів виховання соціальних компетенстностей стедунської молоді в Великобританії. Серед основних іструментів розглядаються парламентські дебати. Автор описує технологію проведення змагання з парламентських дебатів.

Ключові слова: сочіальна компетентність, парламенські дебати, студенський освітній рух «Парламентські дебати»

The article is devoted to the analysis of the tools of education of social competencies of Stedun youth in Great Britain. Parliamentary debates are considered among the main tools. The author describes the technology of holding a parliamentary debate competition.

Key words: social competence, parliamentary debates, student educational movement «Parliamentary debates»

Проблематика розвитку соціальних компетентностей молодих людей $є$ актуальною для всіх освітніх програм усіх країн світу. Само поняття «соціальна компетентність» виникло як поєднання дефініцій «соціал» та «компетентність». Досліджувати це поняття у науковому світі ще у далекому 1959 році почав Роберт Уайт. У його статті «Перегляд мотивації :Поняття компетентності» вводиться поняття «компетентність» та вказується на біологічну значущість такої поведінки. Уайт писав, що мета процесу ефективного навчання взаємодії з навколишнім середовищем невідома тварині або дитині, але внутрішня потреба мати справу з навколишнім середовищем існує та надає особистості задоволення та відчуття ефективності.

Як приклад можливо розглянути систему виховання соціальних компетентностей у Великобританії. В цій країні розроблені та прийняті на законодавчому рівні стандарти соціальної освіти, прийнято декілька урядових директив та програмних документів. Починаючи 3 «Закону про дітей» 2004 року, у якому загальна увага приділяється 5 основним результатам - бути здоровим, залишатися у безпеці, отри- 
мувати задоволення, вносити позитивний внесок у розвиток суспільства та досягати економічного добробуту. Крім того, цей напрямок освіти було закріплено у Соціальних та емоціональних аспектах освіти SEAL та національній стратегії розвитку. Тобто навички соціальних компетентностей починають формуватися у молодих людей Великобританії ще починаючи зі шкільної парти та набувають свого розвитку коли молоді люди приходять до лав університетів.

Одним 3 інструментів виховання соціальних компетентностей студентської молоді Великобританії є участь у парламентських дебатах. Парламентські дебати - це інтелектуальний освітній студентський рух, в основу якого покладена імітація класичних парламентських дебатів. Він сформувався на початку XX сторіччя навколо провідних центрів університетського життя Великобританії та усього світу — міст Оксфорду та Кембриджу. Та саме там сформувалися офіційні стандарти та формати Світових чемпіонатів парламентських дебатів. Перший чемпіонат Мирового турніру парламентських дебатів було проведено у 1980 році в Глазго. Надалі чемпіонати проходили у різних містах Великобританії. Зараз в ньому беруть участь 300 студентських команд з різних коледжів та університетів Великобританії та ще 70 країн світу. Британський формат проведення Мирових турнірів являє собою копію Британського парламенту. Дві команди з одного боку (Команди Уряду) та 2 команди з іншого боку (команди Опозиції) намагаються переконати суддю у правильності своєї точки зору. Такий формат гри дозволяє студентам розвивати свої соціальні компетентності у цікавій для молоді ігровій формі та одразу формує важливі для подальшого суспільного життя soft sklss, а саме : нетворкінг, ораторське мистецтво, вміння відстоювати свою точку зору та підбирати для цього переконливі аргументи. формувати навколо себе команду людей з однаковими поглядами, що допоможуть досягти поставлених цілей, грамотну мову, навички проєктного менеджменту та формування достатнього рівня знань $з$ різних сфер суспільного життя. Особливістю Британського формату студентських парламентських дебатів є наступні моменти. По-перше: імпровізація. Дебатери ознайомлюються з темою дебатів за 15 хвилин до початку змагання та вони можуть користуватися для підготовки будь-якими джерелами знань, крім електронних. Це також формує дуже важливі для подальшого соціального життя компетентності швидко орієнтуватися у життєвих обставинах. що змінюються, 
та зменшує залежність від електронних носіїв інформації. Другою особливістю парламентських дебатів є особлива інформативність. Не знаючи конкретну тему дебатів, яку вони будуть обговорювати, дебатери намагаються накопичувати та систематизувати як найбільший обсяг інформації з дуже широкого спектра проблем. Дуже часто вирішальним для перемоги є саме кількість інформації. Ще однією особливістю є специфічність заходів аргументації. Найбільш поширеним для даного формату є заперечення основних напрямків аргументації, які пропонують опоненти. Важливе значення набуває вміння побудувати власну лінію аргументації таким чином, щоб вона одночасно відбивала або заперечувала лінію аргументації опонентів.

Британський формат проведення Світових турнірів студентського освітнього руху “Парламентські дебати” має велику міжнародну підтримку громадських та міжнародних організацій. Існує Міжнародна освітня асоціація дебатів (IDEA), яка була утворена в 1999 році з метою організовувати та розвивати дебати, а також споріднені форми діяльності. На сьогодні діяльність IDEA - це широкий спектр освітніх та стратегічних ініціатив. Вона організовує дебати більш ніж у 50 країнах світу більш ніж на 60 мовах.

Таким чином, університети Великобританії є не тільки науковими центрами, а й ще освітніми середовищами, де студенти за допомогою різних форм організації їх часу поза межами навчального процесу отримують соціальні компетентності щодо успішної реалізації їх у соціумі, незалежно від професії, яку вони отримують. Одним з таких інструментів $є$ участь студентської молоді в освітньому міжнародному студентському русі Парламентські дебати.

Список використаних джерел:

1. Вальденмайер Ж. Что такое дебаты? И почему они становятся все более и более популярны в современном мире? URL: https:// greenforest.com.ua/journal/read/csho-take-debati-i-chomu-voni-stayut-vsebilsh-i-bilsh-populyarni-v-suchasnomu-sviti

2. Лоуренс X. Як проводити студентські дебати: 6 кроків до конструктивного обговорення URL: https://ahaslides.com/ru/blog/how-tohold-a-student-debate/

3. Caroline, Graham, Fiona. Playing at politics : an ethnography of the Oxford Union (англ.). — Edinburgh: Dunedin Academic Press, 2005. ISBN 978-1281232168 